\title{
Normal ventricular-CSF may confound the diagnosis of tuberculous meningitis hydrocephalus
}

\author{
S. Alfayate-Miguélez; L. Martínez-Lage-Azorín*; L. Marín-Vives; S. García-Martínez**; M.J. Almagro*** and \\ J.F. Martínez-Lage*** \\ Unidad Pediátrica de Enfermedades Infecciosas. *Servicio de Microbiología. **Unidad de Cuidados Intensivos Pediátricos. ***Servicio \\ Regional de Neurocirugía. Hospital Universitario "Virgen de la Arrixaca", Murcia.
}

Summary

Background. The standard procedure for the diagnosis of central nervous system (CNS) infections consists of cerebrospinal fluid (CSF) sampling, which is usually accomplished by a lumbar puncture. However, in some patients presenting with acute hydrocephalus submitted to immediate CSF drainage, the fluid is customarily obtained from the placed draining system. In addition, the CSF obtained from the ventricular and lumbar spaces in some cases may show unusual differences, both in physiological and pathological conditions.

Illustrative cases. We report two children who presented with confounding results in the initial studies of their ventricular and lumbar CSF who were subsequently diagnosed with tuberculous meningitis, causing delay in diagnosis and treatment.

Aim. By reporting these cases, we wanted to alert the treating physician about the possibility of this discrepancy to avoid the delayed diagnosis and management of the affected patients.

Discussion. We comment on the possible pathophysiological mechanisms that may result in this dissociation in ventricular and lumbar CSF composition.

Conclusions. Normal results in CSF studies, especially those of the ventricular fluid, do not always rule out the presence of tuberculous meningitis. We suggest obtaining a CSF sample from the lumbar subarachnoid space in doubtful, or suspicious, cases of CNS infection even in the presence of a normal ventricular CSF.

KEY WORDS. Cerebrospinal fluid. Lumbar CSF. Ventricular CSF. Bacterial meningitis. Tuberculous meningitis hydrocephalus. Infectious hydrocephalus.

LCR ventricular normal: un factor de confusión en el diagnóstico de hidrocefalia por meningitis tuberculosa

Recibido: 20-02-10. Aceptado: 23-02-11
Resumen

Antecedentes. El procedimiento habitual para el diagnóstico de infección del sistema nervioso central (CNS) consiste en el estudio del liquido cefalorraquídeo (LCR) mediante la realización de una punción lumbar. Sin embargo, en pacientes que debutan con un cuadro de hidrocefalia aguda que son tratados de urgencia mediante la inserción de un sistema de drenaje de LCR, el líquido es rutinariamente obtenido desde el sistema derivativo implantado. Pero, en ciertos casos, el LCR ventricular y lumbar analizados pueden mostrar diferencias significativas, tanto en condiciones fisiológicas como patológicas.

Casos ilustrativos. Se describen los casos de dos niños que presentaron resultados dispares en los estudios iniciales del LCR ventricular y lumbar, en los que se demostró posteriormente que padecían una hidrocefalia por meningitis tuberculosa, lo que motivó un considerable retraso en su diagnóstico y tratamiento.

Objetivo. Al describir estos dos casos, pretendemos alertar al médico responsable sobre la posibilidad de esta discrepancia, para evitar retrasos en el diagnóstico y tratamiento de estos pacientes.

Discusión. Se comentan los posibles mecanismos patogénicos que pueden producir esta disociación en la composición del LCR ventricular y lumbar.

Conclusiones. Un resultado normal del LCR, especialmente del líquido ventricular, no descarta siempre la presencia de una meningitis tuberculosa. Sugerimos la obtención de una muestra de LCR a partir del espacio subaracnoideo lumbar en casos dudosos o sospechosos de infección del SNC, incluso ante la presencia de un LCR ventricular normal.

PALABRAS CLAVE. Liquido cefalorraquídeo. LCR lumbar. LCR ventricular. Meningitis bacterianas. Hidrocefalia en meningitis tuberculosa. Hidrocefalia postinfecciosa. 


\section{Introduction}

Clinical manifestations of meningitis are usually obvious and the diagnosis is confirmed by cerebrospinal fluid (CSF) analysis that is usually obtained via a lumbar puncture (LP). The presentation of meningitis with acute manifestations of raised intracranial pressure is a wellrecognized fact. Raised intracranial pressure may result from brain edema, cerebral infarction, venous thrombosis, and hydrocephalus or from a combination of them ${ }^{2}$. Some instances of central nervous system (CNS) infection may evolve with acute hydrocephalus that requires the immediate placement of an external ventricular drainage for prompt relief of intracranial hypertension ${ }^{8}$. Placement of a permanent CSF shunt may even be carried out initially, especially if a CNS infection is not suspected. In cases with drained hydrocephalus, the CSF is obtained from the ventricles during the operation and is routinely sent for study. When the results of the initial CSF are normal or mildly inflammatory, a false feeling of confidence is generated and a right diagnosis may be delayed ${ }^{2,8,12}$.

We report two infants who showed an initially normal ventricular CSF who were subsequently diagnosed with tuberculous meningitis hydrocephalus after analyzing the lumbar CSF. With this report, we wish to emphasize that, in certain cases, the results of ventricular CSF may be discordant with those of the lumbar fluid and to warn the attending physician about this possibility aimed at avoiding a delay in the management of unsuspected meningitis.

\section{Illustrative cases}

Patient 1. An 8-month-old boy was transferred to our hospital with rapid neurological deterioration occurring one week after the onset of a mild respiratory infection. His family and past history were irrelevant. At admission, the child responded only to pain, had a weak cry and showed generalized hypertonus. There were no meningeal signs or fever. An emergency computerized tomography (CT) head scan was performed that revealed severe tetraventricular hydrocephalus with transependymal reabsorption. The child underwent the immediate insertion of a ventriculoperitoneal (VP) shunt that led to a rapid neurological recovery. The CSF obtained during the surgery was completely normal. One week after VP shunting, the boy become drowsy and exhibited a minimal right hypertonus together with low-grade fever. With the clinical suspicion of shunt infection, a reservoir tap was performed that again showed normal CSF results. A CT scan revealed a normalsized ventricular system thus ruling out shunt malfunction. Given the normality of CSF studies, a culture for mycobacteriae was not initially performed. Routine CSF cutures were negative. Two days later, the child became lethargic

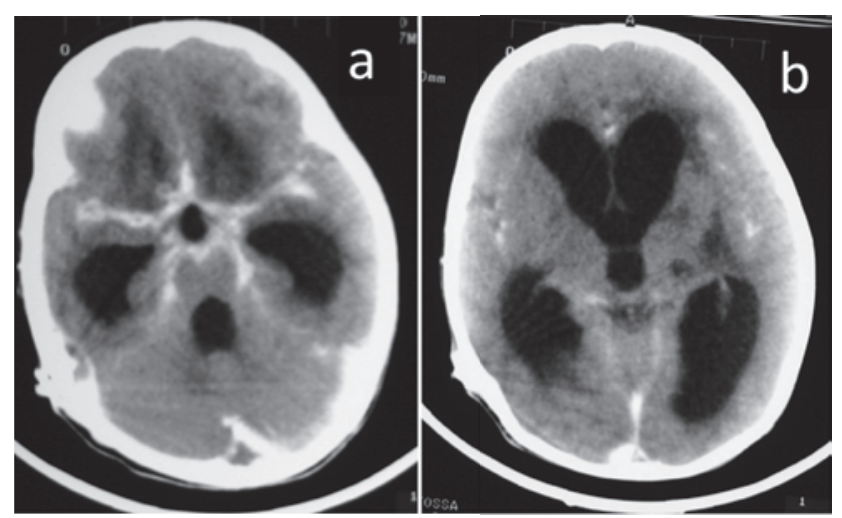

Figure 1. Post-contrast computerized tomography of patient 1 showing basal exudates (a) and hydrocephalus together with an infarction of the left basal ganglia (b).

and his blood analyses evidenced mild leukocytosis and hyponatremia. In view of this ill-defined clinical evolution, we performed an LP that yielded 750 leukocytes $/ \mathrm{mm}^{3}$ (neutrophils $38 \%$ ), protein $5,077 \mathrm{mg} / \mathrm{dL}$, and glucose 20 $\mathrm{mg} / \mathrm{dL}$. Antituberculous treatment with isoniazide, rifampicin, pyrazinamide, and streptomycin was instituted. Post-contrast $\mathrm{CT}$ demonstrated basal exudates and a basal ganglia infarct (Fig. 1a and 1b). The Mantoux test was also positive. The definitive diagnosis was confirmed by growth of Mycobacterium tuberculosis obtained from the lumbar CSF. The subsequent clinical evolution was satisfactory.

Patient 2. An 11-month-old girl was admitted with neurological deterioration that had started after a mild upper respiratory tract infection of 2-weeks evolution. At admission, the child was hyporeactive, drowsy, and with a head tilt. She had mydriatic and unresponsive pupils together with generalized hypotonus and hyperreflexia. Her temperature was normal. A cranial CT scan showed tetraventricular hydrocephalus. An external ventricular drain was immediately placed. The study of the ventricular CSF showed 13 white cells $/ \mathrm{mm}^{3}$, protein $22 \mathrm{mg} / \mathrm{dL}$, glucose $47 \mathrm{mg} / \mathrm{dL}$, and adenosine deaminase (ADA) $5 \mathrm{U} / \mathrm{L}$ 7. After ventricular decompression and a repeat CT study (Fig. 2), an LP was performed that yielded a CSF with 420 white cells $/ \mathrm{mm}^{3}$ (mononuclear $88 \%$ ), glucose $18 \mathrm{mg} / \mathrm{dL}$, and protein $4800 \mathrm{mg} / \mathrm{dL}$. The culture of the lumbar CSF grew a Mycobacterium tuberculosis. The girl was started on isoniazide, rifampicin, pyrazinamide, and streptomycin. Following treatment, the child attained a complete neurological recovery.

\section{Discussion}

CSF is mainly formed in the choroid plexuses of the cerebral ventricles, from here it flows into the subarach- 
noid space of the cerebral hemispheres and is reabsorbed along the sagittal sinus. Part of the CSF also circulates down, around the brain stem and spinal cord, towards the lumbar sac, returning subsequently to the intracranial subarachnoid space. Several mechanisms are involved in the development of hydrocephalus in cases of bacterial meningitis, namely excessive production of CSF by the inflamed choroid plexus, obstacle to its flow, or difficulty for its resorption ${ }^{8}$. In most cases, the mechanism underlying ventricular dilatation is ascertained by estimating the size of the involved cerebral ventricles as seen in the neuroimaging studies. However, neuroimaging has limitations and cannot accurately exclude the presence of raised intracranial pressure ${ }^{1}$.

The composition of ventricular CSF may be different from the lumbar fluid. The characteristics of both ventricular and lumbar CSF may show a great disparity in normal circumstances and in severe pathological conditions $^{5,13}$. In our two patients, the initial or repeat results of the ventricular CSF were normal. Only the clinical suspicion of the possibility of meningitis attracted our attention toward performing an LP that confirmed the diagnosis.

In physiological circumstances, there exists a craniocaudal gradient in the CSF protein content due to aggre- gation of this constituent from the ventricles to the spinal subarachnoid space ${ }^{5,13}$. This difference is higher in CNS infections due to impairment of the blood-brain barrier and to an increase in the protein concentration that modifies the CSF composition at the time that it slows down the circulation of fluid. The concentration of glucose is usually similar in the intracranial and spinal compartments, but in CNS infections, there is a descending gradient, which may be attributed either to sugar consumption by bacteria and leukocytes or more probably to impaired blood-barrier ${ }^{5,13}$.

There are few studies comparing the leukocyte count in ventricular and lumbar CSF, but some preliminary data suggest that there also exists a cranio-caudal gradient in the white cell count ${ }^{5,13}$. In cases of meningitis, migration of neutrophils to the subarachnoid space follows bacterial invasion. Purulent fluid, together with protein increase, slows down the circulation of CSF and impairs its absorption through the arachnoid villi, and by obstructing them, communicating hydrocephalus may develop. The inflammatory exudates can also block the outlets of the fourth ventricle, giving the impression of a non-reabsortive hydrocephalus, when it really is obstructive ${ }^{2,8}$. The inflammatory reaction can also cause obstruction at the foramina of Monro or at the cerebral aqueduct. Although neuroimaging findings in 
our two patients suggested communicating hydrocephalus, ventricular dilatation might also be due to the blockage of CSF at the foramina of Luschka and Magendie, a fact that would explain for the discrepant cytological and biochemical findings between the ventricular and lumbar compartments ${ }^{1,2,8}$.

Some authors suggest that these differences in CSF protein and cell count might also be explained by compartmentalization of the subarachnoid spaces occasioned by infection ${ }^{6}$. Divergences in composition of CSF from these compartments have also been attributed to the diverse location of the infecting focus ${ }^{6}$. Similar differences in ventricular and spinal fluid have been reported in cases of neurocysticercosis, tuberculous and pneumococcal meningitis, and in children with leptomeningeal spread of CNS tumors ${ }^{4,6,9,14}$. Interestingly, Heringer et al. have reported one case with negative ventricular and lumbar CSF cultures, in which only the cisternal CSF yielded acid-fast bacilli ${ }^{6}$.

The diagnosis of bacterial meningitis, or ventriculitis, is based almost exclusively on biochemical and bacteriological analysis of CSF obtained either by an LP or via an external drainage placed in the cerebral ventricles. However, the presence of a normal CSF does not always rule out a diagnosis of meningitis. It has been estimated that approximately $10 \%$ of cases with meningitis may have a normal $\mathrm{CSF}$, which is related with the duration of the disease and with the precocity of the lumbar puncture ${ }^{12}$. Several authors have emphasized the difficulties in diagnosing tuberculous meningitis and publicized diagnostic methods for this condition, aspects that are beyond the scope of our paper ${ }^{3,6,7}$. Early diagnosis and prompt treatment are key in reducing morbidity and mortality from meningitis. However, this diagnosis may be delayed in the presence of non-specific symptoms and signs especially in young children, as occurred in our patients. A more significant pitfall for the correct diagnosis of meningitis can be caused by findings of a normal result in the initial CSF sample, as was the case in our patients.

The usual method for obtaining CSF is by means of an LP. However, in patients given a ventricular drain, CSF is most readily obtained from the drainage itself. In addition, an LP should not be performed in patients who present with impaired consciousness as cerebral herniation may occur even when neuroimaging has been normal ${ }^{2}$. On the other hand, in patients given a ventriculoperitoneal shunt, CSF analysis is routinely performed via the valve reservoir, given that the analysis of shunt fluid is generally regarded as the most reliable method for the diagnosis of a valve infection $^{9,11}$. In our patients, initial CSF sampling was performed directly from the ventricles at the time of VP shunt insertion, via the valve reservoir or from the external ventricular drain respectively. Unfortunately, this represents that we analyzed exclusively the ventricular CSF at the onset. In all occasions, the results of the obtained CSF samples were normal. The differences observed between ventricular and lumbar CSF in our patients could be explained by one, or by a combination, of the pathophysiological mechanisms discussed above: cranio-caudal gradient of CSF components, compartmentalization of the subarachnoid spaces or, most probably, inflammatory blockage to CSF flow.

\section{Conclusions}

The possibility of a mismatch between ventricular and lumbar CSF composition is not an universally recognized fact. We have reported two cases of tuberculous meningitis hydrocephalus, in which the initial ventricular CSF was normal. We suggest that, even in the presence of a normal ventricular CSF, an LP should be performed in cases with ill-defined manifestations of CNS infection to avoid the risk of missing the correct diagnosis and of delaying the appropriate management.

\section{References}

1. Abernethy, L.: Neuroimaging has limitations (letter). BMJ 1999; 318: 122.

2. Cooke, R.S., Patterson, V.: Hydrocephalus was probably non-obstructive (letter). BMJ 1999; 318: 122.

3. Dinnes, J., Deeks, J., Kunst, H., et al.: A systematic review of rapid diagnostic tests for the detection of tuberculous infection. Executive summary. Health Technology Assessment 2007; vol. II, no. 3 (www.hta.ac.uk).

4. Gajjar, A., Fouladi, M., Walter, A.W., et al.: Comparison of lumbar and shunt cerebrospinal fluid specimens for cytologic detection of leptomeningeal disease in pediatric patients with brain tumors. J Clin Oncol 1999; 17: 1825-1828.

5. Gerber, J., Tumani, H., Kolenda, H., Nau, R.: Lumbar and ventricular CSF protein, leukocytes, and lactate in suspected bacterial CNS infections. Neurology 1998; 51: 17101714.

6. Heringer, R.R., Fernandes, L.E., Gonçalves, R.R., Puccioni-Sohler, M.: Localizaçao da lesao e achados do líquido cefalorraqueano na meningite tuberculosa. Diferenças nos compartimentos lombar, cisternal e ventricular. Arq Neuropsiquiatr 2005; 63: 543-547.

7. Kashyap, R.S., Kainthla, R.P., Mudaliar, A., Purohit. H.J., Taori, G.M., Daginawala, H.F.: Cerebrospinal fluid adenosine deaminase activity: a complimentary tool in the early diagnosis of tuberculous meningitis. Cerebrospinal Fluid Research 2006; 3:5 (http://www.cerebrospinalfluidresearch.co $\mathrm{m} /$ content/3/1/5).

8. Mactier, H., Galea, P., McWilliam, R.: Acute obstructive hydrocephalus complicating bacterial meningitis in childhood. BMJ 1998; 316: 1887-1889. 
9. Martínez-Lage, J.F., Martínez-Lage Azorín, L., Almagro, M.J.: Staphylococcus warneri ventriculoperitoneal shunt infection. Childs Nerv Syst 2009; DOI 10.1007/s00381-0091050-0.

10. Naija, W., Mateo, J., Raskine, L., et al.: Case report: Greater meningeal inflammation in lumbar than in ventricular region in human bacterial meningitis. Critical Care 2004; 8: 491-494.

11. Noetzel, M.J., Baker, R.P.: Shunt fluid examination: risks and benefits in the evaluation of shunt malfunction and infection. J Neurosurg 1984; 61: 328-332.

12. Ray, B., Rylance, G.: Normal CSF: does it exclude meningitis? Arch Dis Child 2009; 94: 988-991.

13. Sommer, J.B., Gaul, C., Heckmann, J., Neundorfer, B., Erbguth, F.J.: Does lumbar cerebrospinal fluid reflect ventricular-cerebrospinal fluid? Eur Neurol 2002; 47: 224232.
14. Torres-Corzo, J.G., Tapia-Pérez, J.H., Sánchez-Aguilar, M., Della Vecchia R.R., Chalita Williams, J.C., Cerdá Gutierrez, R.: Comparison of cerebrospinal fluid obtained by ventricular endoscopy and by lumbar puncture in patients with hydrocephalus secondary to neurocysticercosis. Surg Neurol 2009; 71: 376-379.

Alfayate-Miguélez, S.; Martínez-Lage-Azorín, L.; MarínVives, L.; García-Martínez, S.; Almagro, M.J.; Martínez-Lage, J.F.; Normal ventricular-CSF may confound the diagnosis of tuberculous meningitis hydrocephalus. Neurocirugía 2011; 22: 157-161.

Correspondencia: Dr. Juan F. Martínez-Lage. Servicio Regional de Neurocirugía. Hospital Universitario "Virgen de la Arrixaca". 30120 El Palmar, Murcia

e-mail: juanf.martinezlage@cablemurcia.com 